\title{
Modelo conceitual de comunicação da informação para estudos de interação informacional baseado em competências conversacionais em serviço de referência ${ }^{1}$
}

Fernandez Kenji Inazawa

Bibliotecário Especialista em Gestão do
Conhecimento, da Informação e de documentos

Sofia Galvão Baptista Professora da Faculdade de Ciência da
Informação - Universidade de Brasília

O objetivo deste artigo é discutir um modelo conceitual de comunicação da informação aplicável a estudos de interação entre usuário e bibliotecário, baseado em "competências conversacionais" em serviço de referência. Na ciência da informação, o fenômeno das "competências conversacionais" estaria no âmbito da transferência ou da comunicação da informação? Seria o modelo de Shannon e Weaver o mais apropriado para explicar esse fenômeno? Refletindo-se sobre a primeira pergunta, parece haver certa confusão conceitual, quando o assunto é comunicação da informação em ciência da informação. Utilizou-se Barreto (2005) e Pinheiro e Loureiro (1995), como base para a discussão desse aspecto. Com relação à segunda pergunta, talvez, a explicação da adoção do modelo de Shannon e Weaver na ciência da informação se dê pelo estudo dos paradigmas. Como as pesquisas iniciais da ciência da informação, em meados dos anos 50, estavam mais focadas no paradigma físico da recuperação da informação e o modelo de Shannon e Weaver surge mais ou menos na mesma época, a apropriação foi quase imediata. Mas, com a inserção de outros paradigmas, como o cognitivo e o social nos estudos na ciência da informação, o modelo de Shannon e Weaver passou a ser desconstruído e reconstruído sob novas óticas.

1Este artigo fará parte de um trabalho mais amplo sobre competências conversacionais, que servirá como base para o aprofundamento de aspectos comunicacionais em serviço de referência especializado. 
Palavras-chave:

Comunicação da informação; Transferência da informação; conversacionais; Serviço de referência.

\section{Conceptual model of communication of information for informational interaction studies based on conversational competencies in a reference service}

The aim of this paper is to discuss a conceptual model of communication of information applicable to studies of the interaction between user and librarian based on "conversational competencies" in a reference service. In information science would the phenomenon of "conversational skills" be in the transfer or communication of information? Would Shannon and Weaver's model be the most appropriate to explain this phenomenon? Reflecting on that first question, there seems to be a conceptual confusion when the subject is communication of information in information science. We used Barreto (2005) and Pinheiro and Loureiro (1995) as a basis for the discussion of the first question. Regarding the second question, perhaps explaining the adoption of the model of Shannon and Weaver in information science is given through the study of paradigms. Since the early research of information science in the mid-50s were more focused on the physical paradigm of information retrieval and the model of Shannon and Weaver appears at approximately the same time its appropriation was almost immediate. But, with the inclusion of other paradigms such as cognitive and social paradigms in the studies of information science, and also with the emergence of other theories in science communication, the model of Shannon and Weaver came to be deconstructed and rebuilt under new perspectives.

Keywords: Communication of information; Transfer of information; Conversational competencies; Reference service. 


\section{Reflexões epistemológicas sobre o processo de comunicação em ciência da informação}

Em se tratando de comunicação em ciência da informação, há muito o que se discutir, pois o tema é bastante complexo e amplo e, por isso, alguns aspectos foram escolhidos para se chegar a um entendimento mais claro do que seja o tema para a área.

Le Coadic (2004, p. 11) define comunicação como "o processo intermediário que permite a troca de informações entre as pessoas". Através dessa definição, infere-se, de pronto, o caráter social da comunicação na ciência da informação. Porém, algumas considerações são imprescindíveis antes de se pensar em definições para o termo "comunicação".

A primeira consideração é sobre a imprecisão terminológica nas definições encontradas na literatura em ciência da informação. Schrader (1983) apud Capurro e Hjorland (2007, p. 154), após estudar 700 definições para "informação", concluiu que "a literatura em ciência da informação é caracterizada pelo caos conceitual". Talvez, se fosse feito um estudo sobre o termo "comunicação", o caos fosse o mesmo. Consciente das incongruências quanto à formulação de definições para a área da ciência da informação, não constitui objetivo deste trabalho resolver estes impasses, nem propor definições persuasivas para "comunicação".

A exemplo do termo informação, ao se tentar definir "comunicação" para ciência da informação, pode-se incorrer em vários equívocos, pois assim como "informação" é de uso comum a várias áreas do conhecimento, o termo "comunicação" também o é.

A segunda consideração necessária a se fazer é analisar alguns equívocos em Barreto (2005), sobre a diferença que há na ideia de "comunicação", no que se refere ao modelo de Shannon e Weaver nos domínios das ciências da comunicação e da ciência da informação.

A terceira é sobre a sutil diferença entre "comunicação" e "transferência da informação", cujas definições são largamente utilizadas na literatura de ciência da informação, e que, por suas similaridades, são usadas, algumas vezes, como sinônimas. Barreto (2005, p. 1), por exemplo, acha que "a transferência da informação é maior que a simples comunicação". Pinheiro e Loureiro (1995, p. 2) têm opinião diferente, porquanto expressam que "[...] a comunicação pode ser entendida, mais apropriadamente, como transferência da informação".

Muitas teorias nas ciências da comunicação e ciência da informação usam os mesmos modelos de representação gráfica para explicar o processo de comunicação, tanto em uma área quanto em outra. Porém, há um modelo, em específico, que chama a atenção, pois tanto as ciências da comunicação quanto a ciência da informação o utiliza com frequência, que é o do modelo gráfico que explica a Teoria Matemática da 
Comunicação de Shannon e Weaver ${ }^{2}$, sendo que os entendimentos para essas áreas do conhecimento variam quanto aos componentes do modelo; fonte de informação, mensagem, transmissor (codificador), canal, fonte de ruído, receptor (decodificador) e destinação.

Eco $(1972 ; 1984)$ apud Wolf $(1999$, p. 51) salienta que o modelo da Teoria Matemática da Comunicação, quando extrapola a sua intenção original, orientada para explicar como ocorre a transmissão de sinais físicos, pode até ser útil, quando adaptado às Teorias da área de comunicação social, "[...] mas não pode ter mais do que um valor de orientação (sugerindo metáforas ou, no melhor dos casos, possíveis homologias) para uma teoria comunicativa mais abrangente, que só pode ser uma semiótica geral".

Figura 1 - Modelo da Teoria Matemática da Comunicação

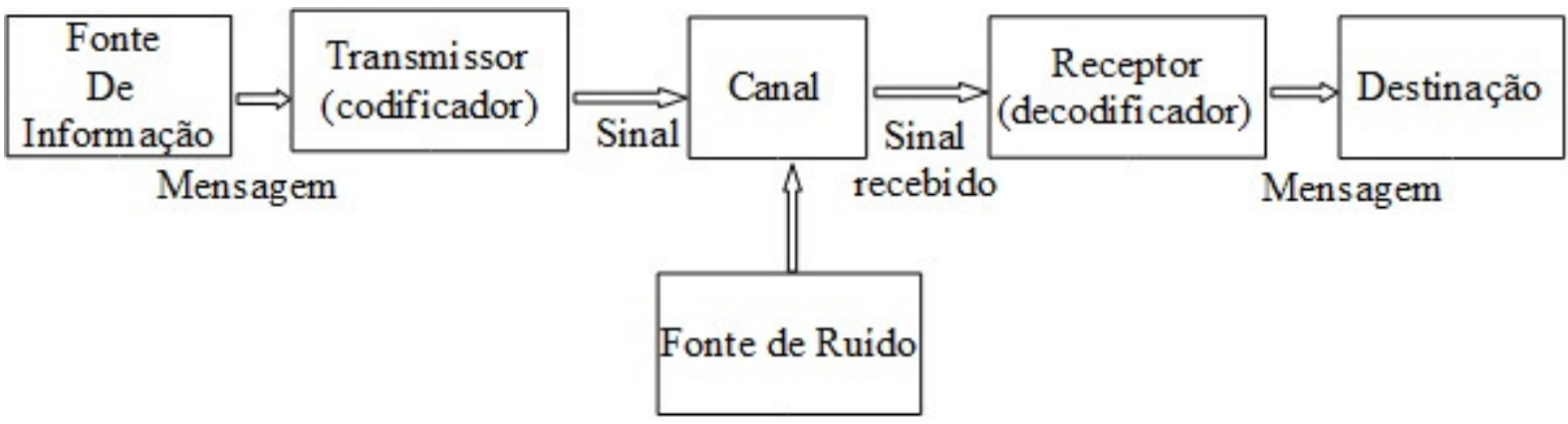

Fonte: Adaptado de SHANNON; WEAVER (1949).

A primeira coisa que chama a atenção no modelo acima, é que a tramitação do sinal é unilateral, partindo da fonte e chegando ao destino, sem retroalimentação do sistema. Wolf (1999, p. 51) é categórico ao afirmar, que, sem dúvida alguma, o modelo de Shannon e Weaver privilegia a visão de transferência física de sinais de um polo a outro e é mais apropriado, quando se circunscreve aos seus objetivos originais.

Apesar dos cuidados que Wolf (1999) recomenda quanto à reinterpretação do modelo de Shannon e Weaver, ele parece ser o esquema mais consensuado entre os autores que tratam sobre epistemologia em ciência da informação. Como exemplo de alguns trabalhos que mencionam a Teoria Matemática da Comunicação, tem-se Buckland (1991), Ingwersen (1992), Pinheiro e Loureiro (1995), Bates (1999), Capurro (2003), Araújo (2003), Matheus (2005) e Zins (2007).

Dentre os estudos acima relacionados, o mais interessante e revelador é o de Zins (2007), o qual tentou formar um panorama abrangente sobre o conceito de ciência da informação e, para tanto, buscou construir um painel baseado na opinião de 57 líderes da área, em 16 países, com o apoio da ferramenta Delphi Crítico. Neste estudo, Wallace Koehler citado por Zins (2007, p. 338) elabora uma definição de

2 Tanto nas ciências da comunicação quanto na ciência da informação, há variantes quanto ao nome da teoria. Ambas a chamam, por vezes, de "Teoria da Informação". Mas, em Wolf (1999), pode-se encontrar, por exemplo, a variante "Teoria Informacional da comunicação". 
ciência da informação, na qual a importância do modelo de Shannon e Weaver é explicitamente demonstrada:

Information science is the totality of the process of communication and understanding, both intra-and interpersonally. As such, it is a broad discipline, ranging from Shannonesque info theory to semiotics and memetics. Information Science is such a broad field that no single meaningful definition is possible unless we seek to limit it and define its other characteristics as something else.

É quase impossível explicar sobre a origem do interesse da ciência da informação pelo modelo de Shannon e Weaver sem tocar no assunto dos paradigmas. Para se compreender as questões epistemológicas da ciência da informação, Capurro (2003) diz ser essencial investigar os paradigmas da área, pois há que se considerar que houve uma evolução paradigmática importante no decorrer dos anos. Saber, portanto, o que seja paradigma é o primeiro passo para a análise. Orom (2000, p. 14) define paradigma como sendo, basicamente, um conjunto de ideias.

Capurro (2003, p.3) cita três paradigmas como sendo os principais para a ciência da informação, que são o físico, o cognitivo e o social:

Minha tese é que a ciência da informação nasce em meados do século XX com um paradigma físico, questionado por um enfoque cognitivo idealista e individualista, sendo esse, por sua vez substituído por um paradigma pragmático e social [...].

Na visão de Capurro (2003), mais tarde, a ciência da informação reinterpreta o modelo de Shannon e Weaver, acrescentando a visão de outros dois paradigmas: o cognitivo e o social. A própria Teoria das Mensagens de Capurro (2003) constitui um dos exemplos de releitura dos elementos do modelo de Shannon e Weaver, na qual emissores e receptores são chamados de mensageiros.

Em Ingwersen (1992), nota-se que o escopo da ciência da informação, no início da década de 90, abrangia estudos relacionados à transferência da informação baseada em sistemas cognitivos, na informação desejada, na efetividade e transferência da informação, nas relações entre informação e produtores e, também, entre informação e usuários.

Parece que o paradigma físico da recuperação da informação foi uma das razões pela qual a ciência da informação se valeu, em um primeiro momento, do modelo de comunicação de Shannon e Weaver, o qual é totalmente voltado para a transmissão física de sinais telefônicos. Apesar dessa aplicação física, com o decorrer do tempo, de acordo com Eco (1972) apud Wolf (1999), o modelo de Shannon e Weaver foi adaptado por outras áreas do saber, servindo de base para outros tipos de 
teorias da comunicação, expandindo-se em variadas versões, com algumas modificações em sua terminologia. Eco (1972) apud Wolf (1999, p. 43) ressalta a flexibilidade do modelo de Shannon e Weaver, ao constatar que todo o processo de comunicação pode ser retratado através dele, quer se verifique:

A. Entre duas máquinas (por exemplo, a comunicação [entre] os aparelhos ditos homeostáticos, os quais asseguram que uma dada temperatura não ultrapasse o limite fixado, predispondo oportunas correções da situação térmica na fonte, [assim que] recebam uma mensagem convenientemente codificada);

\section{B. Entre dois seres humanos;}

C. Entre uma máquina e um ser humano (é típico o caso do nível de gasolina que existe no reservatório de um automóvel, que é comunicado através de uma bóia e de sinais eléctricos ao tablier do automóvel, onde aparece uma mensagem dirigida ao condutor.

Para explicar sobre a conexão entre o paradigma físico da ciência da informação e o modelo de Shannon e Weaver e, ainda, fornecer uma explicação sobre o porquê da ciência da informação ter tomado emprestado tal modelo, Ellis (1992) e Orom (2000) apud Capurro (2003, p. 6) discorrem que:

A ciência da informação inicia-se como teoria da recuperação da informação baseada numa epistemologia fisicista. A esse paradigma, intimamente relacionado com a assim chamada information theory de Claude Shannon e Warren Weaver (1949-1972) [...] e também com a cibernética de Norbert Wiener (1961), denominou-se o paradigma físico.

De acordo com Barreto (2005), nas ciências da comunicação, o gerador é uma instituição ou um grupo; e os receptores, a massa, ou seja, um grupo heterogêneo de indivíduos. A impessoalidade entre gerador e receptores é forte. A mensagem tem conteúdo semântico fraco e é decorrente do canal, sendo passada de um ponto a outro sem muita preocupação com a assimilação exata do conteúdo pelos receptores, pois o objetivo é alcançar o maior público possível. Portanto, a comunicação se molda aos objetivos da mensagem, que é transmitir com rapidez o fato, apresentando ao receptor algo totalmente novo ou acrescentando novidade a mensagens anteriores. O domínio do processo está nas mãos do canal, que transfere mensagens a um público genérico, com a intenção de difundir os interesses de grupos, moldando, influenciando ou entretendo os receptores. O meio de comunicação tem o poder de impregnar a mensagem, podendo se transformar na própria mensagem. 
Na ciência da informação, contudo, os objetivos são diferentes. Ela desenvolve métodos de investigação das necessidades do receptor, com o intuito de gerar informações adequadas. Segundo Barreto (2005, p. 1), "a ciência da informação caracteriza o seu gerador, nomeia seus autores, estuda as necessidades e faz um perfil do receptor, [o qual] pode ser somente um indivíduo ou um grupo com coesão afetiva de interesses informacionais." Barreto (2005) complementa dizendo que, na ciência da informação, a comunicação entre os interlocutores precisa de conexão psicológica e compartilhamento de um contexto verbal ou passível de verbalização, com um código que seja compreendido ao menos parcialmente entre emissor e receptor. Nesse sentido, a comunicação é vista como relações humanas; um esforço de articulação mútua entre indivíduos para se compreenderem.

Barreto (2005) defende que o processo de comunicação, visto através do modelo de Shannon nas ciências da comunicação e na ciência da informação, tem acepções distintas. A comunicação, grosso modo, nas ciências da comunicação, "transfere mensagens" sem se ater muito ao seu conteúdo, porquanto é direcionado à massa, com impessoalidade. Os receptores, nesse caso, são quase que ignorados em suas diferenças sociais e capacidades cognitivas individualizadas. Quando se recorre à literatura especializada das ciências da comunicação, como em Wolf (1999) percebe-se o que Barreto (2005) afirma é polêmico e demonstra uma visão um pouco superficial de interpretação do modelo de Shannon e Weaver nas ciências da comunicação, pois considera, apenas, os primórdios da comunicação de massa, a Teoria Hipodérmica da Comunicação que, há muito tempo, se considera ultrapassada ${ }^{3}$.

Pode-se mencionar, como exemplo de teoria da comunicação que faz uso do modelo de Shannon e se preocupa com a interpretação cognitiva e social dos indivíduos nas ciências da comunicação, a "Teoria da Recepção", que White (1998) também denomina de "Interpretação da Audiência da Mídia", na qual leva em consideração a inter-relação entre emissores e receptores, bem como a construção de significados por parte dos receptores. Essa teoria tem como premissa que os meios de comunicação possuem o poder de criar significados culturais e, por isso, não são apenas meios que transportam informação.

Na ciência da informação, quando se transfere uma mensagem, há que se considerar o seu conteúdo, ou melhor, a informação contida nela; esse processo se chama transferência da informação, a qual tenta lidar com as peculiaridades de grupos de usuários.

Segundo Barreto (2005, p. 1), a característica mais distintiva entre comunicação e transferência da informação é a noção de passagem de um ponto a outro:

3Além de Wolf (1999), consultar outros autores que falam sobre a história da comunicação, a evolução de suas teorias, conceitos e processos, tais como: Berlo (1972), Melo (1977), Pasquali (1990), Bougnoux (1999), Iguartua e Humanes (2004), Marcondes Filho (2008). 
$\mathrm{Na}$ transferência da informação tem-se a idéia de deslocamento, uma mudança de dados de uma área ou meio de armazenamento para outra área ou meio de armazenamento [...]. Todas as intenções se orientam para o destino final: não basta atingir o receptor, há que criar conhecimento modificador em pessoas únicas. A transferência da informação distribui informação para formar um melhor conhecimento para o desenvolvimento da realidade.

Percebe-se que, na transferência da informação, há uma grande preocupação em se construir uma mensagem com conteúdo apropriado, pois ela tem objetivos claros de desenvolver mudanças significativas no conhecimento dos indivíduos. Portanto, o foco está na mensagem, pois, para Barreto (2005, p.1), é ela quem irá conectar emissor e receptor durante o processo. Um exemplo de transferência da informação seria uma instituição, como a Empresa de Assistência Técnica e Extensão Rural (EMATER), elaborar um manual ensinando como se criar galinhas. Para se transferir com eficácia a informação, parte-se do pressuposto de que basta conhecer o público e adequar o conteúdo.

Em Pinheiro e Loureiro (1995), não se percebe a diferença entre comunicação e transferência da informação, talvez, porque o fenômeno da comunicação seja visto como mais abrangente e englobe a transferência. Wolf (1999, p. 51) tem o mesmo raciocínio por considerar que a comunicação tem duas acepções: transferência de informação entre dois pólos e transformação de um sistema em outro sistema.

\section{Modelo conceitual de comunicação para estudos de interação entre usuário e bibliotecário em serviços de referência}

Como visto, o modelo de Shannon e Weaver pode ser adaptado a outras situações que extrapolem a sua intenção original de explicar como ocorre o processo de transmissão de sinais físicos. A ciência da informação foi uma das áreas que percebeu esse potencial, reinterpretando o modelo segundo os seus interesses de estudo, atribuindo-lhe o cognitivo e o social.

Ao se pensar em algum modelo de comunicação (e não de transferência da informação) para pesquisas que envolva a comunicação humana, é necessário dizer que elas estão classificadas na área de ciência da informação, genericamente, no escopo dos "estudos de uso da informação", mais precisamente na parte da "interação informacional".

Conforme Le Coadic (2004, p. 45-47), a ciência da informação se interessa em investigar três tipos de interações informacionais:

- entre pessoas (P-P);

- entre pessoa-computador (P-C); e 
- entre pessoa-computador-pessoa (P-C-P).

Ao analisar a interação P-P, Le Coadic (2004, p. 45) afirma que o ato de se negociar uma questão em um processo de referência é de alta complexidade e exige sucessivas interações informacionais, pois "a primeira questão nem sempre expressa as reais intenções do usuário". Portanto, o bibliotecário, ao desenvolver o processo de referência, deverá auxiliar o usuário em sua necessidade de informação através do diálogo, o que, segundo Echeverría (2003), poderia ser aprimorado através de "competências conversacionais".

De acordo com Le Coadic (2004, p. 44), o diálogo é o componente central de todo sistema de informação e significa uma conversa orientada para um objetivo, um ato de comunicação cooperativo, ou seja, "que impõe certas regras de cooperação". Em unidades de informação, o diálogo pode ocorrer entre pessoas ou, ainda, entre pessoas e sistemas computacionais.

De posse da discussão realizada até agora, a respeito da limitação do modelo de Shannon e Weaver e sobre a diferença entre comunicação e transferência da informação, um possível modelo de comunicação aplicável a estudos que envolvam a interação informacional entre usuário e bibliotecário, poderia ser o de Diaz Bordenave (1995, p. 26), porquanto considera "comunicação como processo de interação humana que se realiza mediante signos organizados em mensagens".

De acordo com Diaz Bordenave (1995, p. 16), duas pessoas não possuem a mesma percepção da realidade, porque na "[...] dinâmica mental interna de A e B consta repertórios diferentes de experiências, conhecimentos, crenças, valores, atitudes. A e B possuem também, repertórios diferentes de signos e, segundo parece, os signos influenciam a percepção".

E não são apenas os filtros mentais dos interlocutores que fazem com que cada um tenha uma interpretação diferente da realidade objetiva. Em se tratando de competências conversacionais, a observação é algo muito particularizada, e leva em conta, além do cognitivo, também - emocional e as estruturas biológicas distintas, que interferem na percepção e conferem à realidade significados interpretativos.

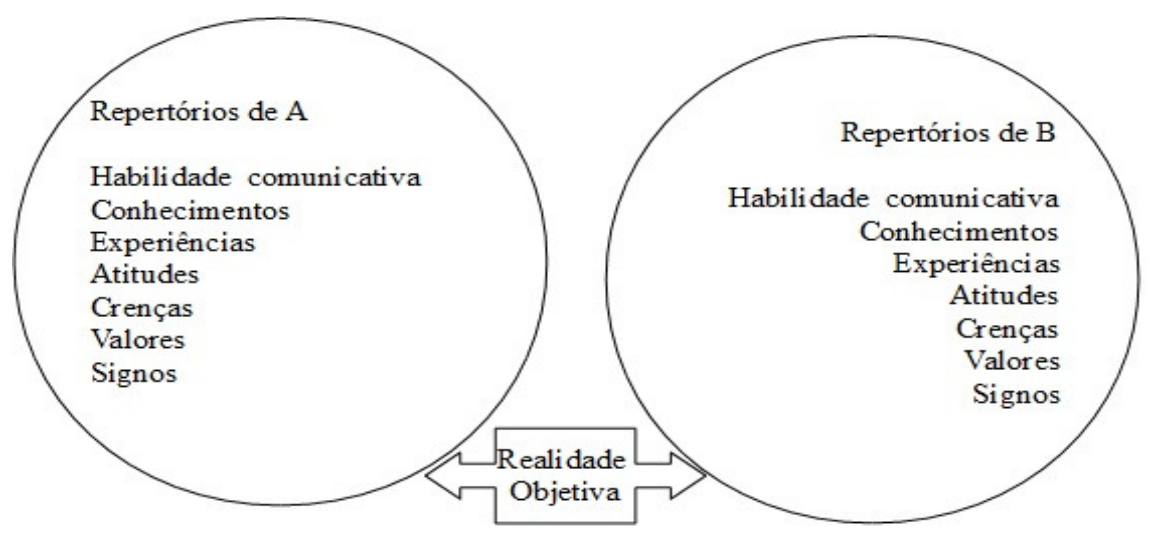


Figura 2 - Repertórios de A e B

Fonte: Adaptado de DIAZ BORDENAVE (1995).

Excetuando-se os casos em que o usuário tem a intenção de apenas obter um síntese do acervo sobre determinado assunto, em bibliotecas especializadas, tais como de Medicina, Direito e Agropecuária, presume-se que o levantamento das necessidades informacionais exija maior acurácia na comunicação entre bibliotecário e usuário, por se tratar de demanda bem mais precisa e atualizada. Em algumas situações, se houver erro no fornecimento do produto de informação, isso poderá ocasionar danos consideráveis. Competências conversacionais serviriam, à priori, como ferramenta de trabalho imprescindível para o bibliotecário, nesses casos, por considerar o fenômeno da comunicação humana problemático, o que demandaria desenvolver habilidades, como escutar efetivamente, indagar e expor de forma produtiva, saber pedir, ofertar e prometer a entrega de produtos de informação em uma base satisfatória.

Fundamentando-se nos conhecimentos da Ontologia da Linguagem de Echeverría (2003), para esse artigo, competência conversacional é o uso da comunicação através de conhecimentos, habilidades, atitudes e valores, com o propósito de aumentar o entendimento e a cooperação entre os indivíduos. A variável "conhecimento" se refere à linguagem, à emocionalidade e à corporalidade; também diz respeito a considerar a diferença entre as pessoas (observadores), às dificuldades de comunicação, à importância das expectativas nos relacionamentos. As habilidades são o escutar, o expor, o indagar, o ofertar e o pedir. As atitudes são o comprometimento, a responsabilidade e a pró-atividade. Os valores são a sinceridade, a ética, o respeito e a responsabilidade.

Transpondo-se o modelo da comunicação humana de Diaz Bordenave (1995) para o processo de referência, o início da interação linguística se dará quando os usuários e bibliotecários trocarem mensagens entre si. O que é pedido entrará em contato com o repertório mental do bibliotecário, o que gerará uma interpretação com "significado pessoal".

Com o intercâmbio de mensagens, o usuário e o bibliotecário construirão um contexto compartilhado, modificando seus significados pessoais. Diaz Bordenave (1995, p. 19) diz que, durante a formação do contexto, "idealmente ocorre ao mesmo tempo uma aproximação emocional que permite a aceitação do outro e a continuação do diálogo. $\mathrm{Na}$ medida em que o processo de comunicação vai se aprofundando, A e B caminham para uma certa comunhão". 
Figura 3 - Significados iniciais e compartilhados

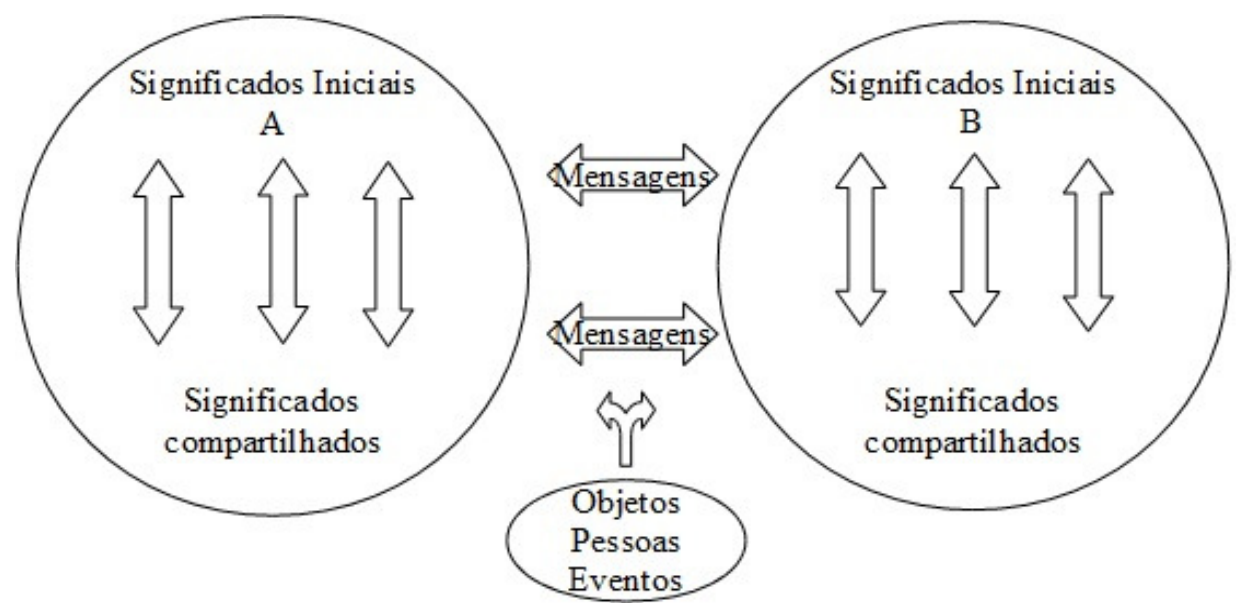

Fonte: Adaptado de DIAZ BORDENAVE (1995).

Com o emprego da competência conversacional do "escutar efetivo" de Echeverría (2003), o bibliotecário ampliaria a sua capacidade de ouvir, processar e compreender o contexto da mensagem, não somente averiguando a escuta através da reprodução oral de um resumo ao usuário do que entendeu sobre sua questão de referência, mas, também, checando as inquietudes quanto ao pedido (a importância do pedido, a urgência, a pressão por prazos, etc.). A escuta efetiva precisa estar presente desde a primeira troca de mensagens, quando o bibliotecário e usuário discutem a questão de referência, para clarear a necessidade de informação para ambos; no meio do processo, quando ele acerta com o usuário o prazo e as condições de satisfação do pedido (o formato de apresentação - número de referências bibliográficas, separação dos resultados por tema, por ano, por autor, etc.), até o fim do processo, quando os resultados da busca irão ser apresentados e avaliados por ambos, renegociando-se o pedido ou não.

Em complemento ao "escutar efetivo", tem-se a competência conversacional do "indagar e expor produtivos" de Kofman (2004). Sua função principal é revelar as conversas íntimas ao outro, as bases do raciocínio que dão corpo ao discurso oral. Por exemplo, revelar o quanto não se conhece sobre o pedido do usuário; dizer, quando necessário, que não compreendeu ou não será possível atender a necessidade de informação; comunicar o prazo de entrega do produto de informação, tendo em vista as condições reais de execução da busca; não se sentir conhecedor exclusivo das fontes de informação ao perguntar ao usuário sobre o conhecimento de outras fontes; e comunicar dados preliminares no meio do processo de busca. O "indagar e expor produtivos" servem, também, para refinar a questão de referência, ao se formular perguntas sobre o problema, remontando às origens da necessidade de informação, caso o usuário esteja em dúvida de qual seja a sua necessidade real. Outra aplicação dessa competência poderia resultar no uso adequado de 
feedback, potencializando a habilidade de argumentar com coerência, dissolvendo possíveis conflitos na interação entre as partes.

Saber formular pedidos, ofertas e prometer a entrega de produtos de informação em bases confiáveis é mais uma das competências conversacionais que poderia contribuir para a eficácia no processo de referência.

Sobre os pedidos dos usuários, o bibliotecário que visa se comunicar eficazmente, deve ponderar sobre as diferentes formas linguísticas e de raciocínio de quem emite um pedido, bem como a emocionalidade dos indivíduos que, muitas vezes, se constituem em barreiras de comunicação. Saber recusar ou remodelar pedidos é tão útil quanto o desejo sincero de querer atender a todas as demandas, pois influencia diretamente na relação de satisfação do usuário com relação ao serviço prestado. A referida postura tem a ver com a sinceridade e competência de quem oferta.

Depois de esclarecida a questão de referência para ambos os interlocutores, da aceitação dos pedidos, passa-se à oferta de um produto de informação ao usuário. Uma oferta precisa ter bem clara as características do produto que serão entregues, o que tem haver com a habilidade de saber ofertar com consistência, que é o ato de combinar com o usuário condições satisfatórias de formato de apresentação, quantidade de referências ou textos e prazo de entrega.

No entanto, as condições de satisfação, por si mesmas, não caracterizam uma promessa de entrega de um produto de informação, enquanto não houver uma declaração de aceitação das condições pelos interlocutores. O procedimento, então, é checar as condições de satisfação do pedido antes de fechar a negociação da entrega do produto. Sem este cuidado, poderá ocorrer a frustração das expectativas, porque o bibliotecário, equivocadamente, poderá entender que irá entregar " $X$ " e 0 usuário receber " $Y$ ".

Quando não se prima por uma comunicação eficaz dentro das organizações, aumentam-se os conflitos causados pelos mal entendidos e a imagem do profissional e da empresa podem ser atingidos. Para que ocorra uma comunicação eficaz, segundo Chiavenato (2010, p. 317) é preciso gerenciar a atenção, o significado e a confiança.

O gerenciamento da atenção é estar atento a tudo no ambiente de trabalho. E, para as competências conversacionais, é estar sempre interessado no que o outro fala, bem como em todo gestual e emocionalidade que estão ocorrendo durante a conversa.

Gerenciar o significado é um trabalho árduo na comunicação, pois é averiguar, a todo instante, se o sentido das mensagens se mantém unívoco e claro para quem emite e recebe. Em competências conversacionais, essa atitude corresponde ao escutar ativo.

$\mathrm{E}$, talvez, o mais complicado em se gerenciar na comunicação seja a confiança, porque nem sempre é possível gerar abertura e confiabilidade. O requisito principal para a confiança é o comprometimento com os 
relacionamentos entre as pessoas e com a organização. Quando há competência conversacional, o diálogo é baseado fundamentalmente na sinceridade e confiabilidade de quem promete executar a tarefa

\section{Considerações finais}

Mesmo sabendo que as definições científicas não conseguem abranger, em sua totalidade, os fenômenos a que se propõem descrever, o esforço de construir e aplicar adequadamente termos, como "comunicação e transferência da informação", precisam ser perseguidos para que não se amplie o caos conceitual existente (cita-se o caso do termo informação) na ciência da informação. Além de esclarecer essa questão epistemológica, a discussão serviu como apoio, ao localizar o tema "competência conversacional" na área.

Como visto, as competências conversacionais estão situadas no escopo da comunicação da informação e não da transferência, pois é um fenômeno de interação informacional com foco nas pessoas, para o qual se exigem conhecimentos, habilidades e atitudes, tais como o escutar efetivo, o indagar e o expor produtivos, o saber elaborar pedidos, ofertar e prometer com eficácia.

No que tange à escolha de um modelo de comunicação ajustado ao fenômeno conversacional entre bibliotecário e usuário, em um processo de referência, é necessário visualizá-los não apenas como emissores e receptores de mensagens, mas incluir as suas crenças, valores, experiências, habilidades linguísticas e comunicacionais diferenciadas. 0 modelo de Diaz Bordenave (1995) poderia servir como proposta para representar as conversas em um processo típico de referência em bibliotecas.

Mas, o assunto "competências conversacionais" gera muitas reflexões que vão além da tentativa da escolha de modelos de comunicação. Uma possível reflexão seria que o uso ostensivo do e-mail, como canal de comunicação entre usuário e bibliotecário, pudesse encurtar a cadeia do processo de referência, dispensando-se a etapa final. Autores como Grogan (1995) e Figueiredo (1996), por exemplo, ao escreverem sobre as etapas do serviço de referência, dizem que a sua última parte seria a negociação com o usuário, do resultado da busca empreendida pelo bibliotecário. Através de rápida observação em biblioteca universitária feita pelos autores deste artigo, constatou-se que o resultado da pesquisa bibliográfica era repassado diretamente por e-mail como "produto final" da pesquisa, sem checar com o usuário se a lista de referências satisfazia ou não o seu pedido. Será que em bibliotecas especializadas estaria ocorrendo o mesmo? Qual seria, então, o uso que esses bibliotecários fazem das competências conversacionais no dia a dia do processo de referência?

Como visto em Chiavenato (2010), a falta de gerenciamento da comunicação dentro das organizações coloca em risco a imagem, tanto do profissional quanto da própria instituição. Em se tratando de atendimento 
em bibliotecas especializadas, talvez, a prática de competências conversacionais auxiliasse na comunicação eficaz, tanto virtual como presencial.

Como a ciência da informação herdou da biblioteconomia o caráter social, novas pesquisas poderiam ser incentivadas no campo de estudos de usuários, pois, no passado, estudou-se muito sobre serviço de referência, mas há uma carência, na atualidade, de estudos sobre a interação usuário e bibliotecário, mais precisamente no que se refere à comunicação.

\section{Referências}

ARAÚJO, C. A. Á. A ciência da informação como ciência social. Ciência da Informação, Brasília, v. 32, n. 3, p. 21-27, set./dez. 2003.

BARRETO, A. de A. A estrutura do texto e a transferência da informação. DataGramaZero, Rio de Janeiro, v. 6, n. 3, jun. 2005. Disponível em: <http://dgz.org.br/jun05/F_I_art.htm>. Acesso em: 15 fev. 2012.

BATES, M. The invisible substrate of information science. Journal of American Society of Information Science, v. 50, n. 2, p. 1043-1050, 1999.

BERLO, D. K. O processo da comunicação. 4. ed. São Paulo: Martins Fontes, 1972.

BOUGNOUX, D. Introdução às ciências da comunicação. Bauru: Edusc, 1999.

BUCKLAND, M. K. Information as thing. Journal of the American Society for information Science, v. 42. n. 5. p. 351-360, 1991.

CAPURRO, R. Epistemologia e ciência da informação. In: ENCONTRO NACIONAL DE PESQUISA EM CIÊNCIA DA INFORMAÇÃO, 5., Belo Horizonte, 2003. Anais... Belo Horizonte: ANCIB, 2003.

CAPURRO, R.; HJøRLAND, B. O conceito de informação. Perspectiva em Ciência da Informação, Belo Horizonte, v. 12, n. 1, p. 148-207, jan./abr. 2007.

CHIAVENATO, I. Comportamento organizacional: a dinâmica do sucesso das organizações. 2. ed. Rio de Janeiro: Elsevier, 2010.

DIAZ BODERNAVE, J. E. D. Além dos meios e mensagens: introdução à comunicação como processo, tecnologia, sistema e ciência. 7. ed. Rio de Janeiro: Vozes, 1995.

ECHEVERRIA, R. Ontologia del lenguaje. Santiago: Dolmen, 2003.

ECO, U. Estetica e teoria dell'informazione. Milano: Bompiani, 1972 apud WOLF, M. Teorias da Comunicação. Lisboa: Presença, 1999.

ELLIS, D. Paradigms and proto-paradigms in information retrieval research. In: 
VAKKARI, P.; CRONIN, B. (Orgs.). Conceptions of Library and Information Science: Historical, empirical and theoretical perspectives. London: Taylor Graham, 1992. p. 165-186.

FIGUEIREDO, N. M. de. Serviços de referência e informação. São Paulo: Polis, 1992.

GROGAN, D. A prática do serviço de referência. Brasília: Briquet de Lemos, 1995.

IGARTUA, J. J.; HUMANES, M. L. Teoría e Investigación en Comunicación Social. Madrid: Síntesis, 2004.

INGWERSEN, Peter. Information science in context. In. Information retrival interaction. London: Taylor Graham, 1992. p. 1-14.

KOFMAN, F. Metamanagement: o sucesso além do sucesso. Rio de Janeiro: Elsevier, 2004.

LE COADIC, Y.-F. A ciência da informação. 2. ed. Brasília: Briquet de Lemos/Livros, 2004.

MARCONDES FILHO, C. Para entender a comunicação: contatos antecipados com a nova teoria. São Paulo: Paulus, 2008.

MATHEUS, R. F. Rafael Capurro e a filosofia da informação: abordagens, conceitos e metodologias de pesquisa para a Ciência da Informação. Perspect. Ciên. Inf., Belo Horizonte, v. 10, n. 2, p. 140-165, jul./dez. 2005.

MELO, J. M. de. Comunicação social: teoria e pesquisa. 6. ed. Petrópolis: Vozes, 1978.

OROM, A. Information science, historical changes and social aspects: a Nordic outlook. Journal of Documentation, v. 56, n. 1, p. 12-26, jan. 2000.

PASQUALI, A. Comprender la comunicación. 4. ed. Caracas: Monte Avila Latinoamericana, 1990.

PINHEIRO, L. V. R.; LOUREIRO, J. M. M. Traçados e limites em ciência da informação. Ciência da Informação, Brasília, v. 24, n. 1, p. 1-19, 1995

SCHRADER, A. M. Toward a theory of library and information science. 1983. Tese (Doutorado) - Indiana University, 1983 apud CAPURRO, R.; HJØRLAND, B. O conceito de informação. Perspectiva em Ciência da Informação, Belo Horizonte, v. 12, n. 1, p. 148-207, jan./abr. 2007.

SHANNON, C. E.; WEAVER, W. The Mathematical Theory of Communication. Urbana: University of Illinois Press, 1949.

WHITE, R. A. Recepção: a abordagem dos estudos culturais. Comunicação e Educação, São Paulo, v. 12, n. 4, p. 57-76, maio/ago. 1998.

WOLF, M. Teorias da Comunicação. Lisboa: Presença, 1999. 
Modelo conceitual de comunicação da informação para

ZINS, C. Conceptions of information science. Journal of the American Society for Information Science and Technology, v. 58, n. 3, p. 335-350, 2007. 